\title{
Redox-dependent phosphorus burial and regeneration in an offshore sulfidic sediment core in North Yellow Sea, China
}

\author{
Guoqiang Zhao ${ }^{\mathrm{a}, \mathrm{b}}$, Yanqing Sheng ${ }^{\mathrm{a}, *}$, Ming Jiang ${ }^{\mathrm{a}, \mathrm{b}}$, Xiuli Yin ${ }^{\mathrm{a}}$ \\ ${ }^{\text {a }}$ Research Center for Coastal Environment Engineering Technology of Shandong Province, Yantai Institute of Coastal Zone Research, Chinese Academy of Sciences, Yantai, \\ China \\ ${ }^{\mathrm{b}}$ University of Chinese Academy of Sciences, Beijing, China
}

\section{A R T I C L E I N F O}

\section{Keywords:}

$P$ sequential extraction

${ }^{31} \mathrm{P}$ NMR

Sulfide

Redox

Marine sediments

\begin{abstract}
A B S T R A C T
Phosphorus (P) pollution can trigger severe marine eutrophication, which further leads to harmful algal blooms, and a deterioration of sea water quality. The $\mathrm{P}$ burial and regeneration in offshore sediments can directly affect the eutrophication levels of estuarine and coastal ecosystems. Although many researches on redox-dependent P burial and regeneration were studied, such process in the presence of silicate is still poorly understood, and the effects of pyrite formation on organic P (OP) burial and regeneration also remain unclear. In this study, a sulfidic sediment core was collected in the offshore of an estuary in the north Yellow Sea, China. Results indicated that indigenous biological input was found to be the primary source of organic matter in upper sediments. The regenerated $\mathrm{P}$ under reducing conditions was dominated by labile $\mathrm{Fe}-\mathrm{P}$ and $\mathrm{OP}$. The $\mathrm{PO}_{4}{ }^{3-}$ released from $\mathrm{Fe}-\mathrm{P}$ and $\mathrm{OP}$ that could be captured by $\mathrm{Al} / \mathrm{Fe} / \mathrm{Mn}$ (oxyhydr) oxides in surface sediments and $\mathrm{Ca}$ minerals in deep sediments. $\mathrm{Ca}-\mathrm{P}, \mathrm{Al}-\mathrm{P}$, unreactive $\mathrm{Al} / \mathrm{Fe}-\mathrm{Si}-\mathrm{P}$ and some stable metal chelated $\mathrm{OP}$ were the main burial $\mathrm{P}$ fractions. Sulfate reduction and formation of insoluble metal sulfides including the pyrite promoted OP decomposition by anaerobic decomposition, removing metal ions from the "metal-OP" chelates and restoring the phosphatase activity.
\end{abstract}

\section{Introduction}

Phosphorus (P) is an essential nutrient for organism growth and a limiting factor for marine primary productivity (Smith, 1984). Although $\mathrm{P}$ is removed from marine systems by burial in sediment, abundant $P$ accumulated in sediment can be regenerated into the overlying water, contributing to algal blooms (Eijsink et al., 2000). The mechanisms of sedimentary $\mathrm{P}$ burial and regeneration are closely related to the sediment redox, $\mathrm{P}$ speciation, and sulfidic conditions ( $\mathrm{Li}$ et al., 2016; Sun et al., 2016; Zhao et al., 2019b).

In upper sediments with oxidizing condition, soluble reactive phosphorus (SRP) from the overlying water and regenerated $\mathrm{PO}_{4}{ }^{3-}$ from the decomposition of organic $\mathrm{P}(\mathrm{OP})$ in plant debris are captured by $\mathrm{Al} / \mathrm{Fe} /$ $\mathrm{Mn}$ (oxyhydr) oxides and Ca compounds transforming into $\mathrm{Al} / \mathrm{Fe} / \mathrm{Mn}$ (oxyhydr) oxides-bound $\mathrm{P}$ (Al/Fe/Mn-P) and $\mathrm{Ca}$ compounds-bound $\mathrm{P}$ (Ca-P) (Zhu et al., 2013; Li et al., 2018). In deep sediments with reducing condition, sulfate reduction becomes strong, accompanied by dissolved sulfide and ferrous iron (Fe II) accumulation. The Fe-bound P can be released during ferric iron (Fe III) reductive dissolution, and the generated $\mathrm{Fe}(\mathrm{II})$ rapidly reacts with dissolved $\mathrm{HS}^{-}$(Krom and Berner, 1980). However, the concentrations of Si and $\mathrm{Al}$ are higher than Fe, Mn and Ca contents in marine sediment, which can potentially alter the relationship between bulk sediment geochemistry and P burial mechanisms. For instance, there are many stable Al-bound silicate minerals (e.g., kaolinite, feldspar and dickite) in sediments (Story et al., 2010). P can not only be adsorbed on the surfaces of $\mathrm{Al}$ and/or Fe bound silicate minerals to form stable $\mathrm{P}$ complexes but also be preserved within the silicate minerals by $\mathrm{Al}-\mathrm{OH}$ and $\mathrm{Fe}-\mathrm{OH}$ functional groups through ion exchanges (Kasama et al., 2004; Ruttenberg and Sulak, 2011), which enhance capacity for $\mathrm{P}$ sequestration. The $\mathrm{P}$ within the silicate minerals is called occluded $\mathrm{P}$, which is too stable to be released under natural conditions (Liu et al., 2003). Therefore, to investigate redox-dependent $P$ burial and regeneration mechanism in the presence of $\mathrm{Al} / \mathrm{Fe}$-bound silicate minerals will provide new insights in $\mathrm{P}$ cycling.

$\mathrm{P}$ burial and regeneration is closely related to solid-phase P speciation (Carpenter, 2008; Dijkstra et al., 2018). There are many classical P chemical speciation analysis methods, such as Standards, Measurements and Testing (SMT) Program, Ivanoff organic P (OP) sequential extraction, and solution ${ }^{31} \mathrm{P}$-nuclear magnetic resonance spectroscopy $\left({ }^{31}\right.$ P NMR) (Ivanoff et al., 1998; Ruban et al., 2001; CadeMenun and Liu, 2014). The SMT protocol consists of $\mathrm{NaOH}$-extractable inorganic $\mathrm{P}(\mathrm{Al} / \mathrm{Fe} / \mathrm{Mn}-\mathrm{P}, \mathrm{P}$ bound to $\mathrm{Al}, \mathrm{Fe}$ and $\mathrm{Mn}$ oxides and

\footnotetext{
* Corresponding author.

E-mail addresses: gqzhao@yic.ac.cn (G. Zhao), yqsheng@yic.ac.cn (Y. Sheng), jiangming17@mails.ucas.edu.cn (M. Jiang), xlyin@yic.ac.cn (X. Yin).
} 
hydroxides), HCl-soluble inorganic $\mathrm{P}$ (Ca-P, P associated with $\mathrm{Ca}$ ), OP, and total $\mathrm{P}$ (TP). The Ivanoff method divides OP into readily labile OP, moderately labile OP and nonlabile OP. $\mathrm{Al} / \mathrm{Fe} / \mathrm{Mn}-\mathrm{P}$ and labile $\mathrm{OP}$ are easily released and hydrolyzed into soluble reactive $\mathrm{PO}_{4}{ }^{3-}$, while $\mathrm{Ca}-\mathrm{P}$ and non-labile OP are too reluctant to be easily regenerated (Zhao et al., 2018; Zhu et al., 2018). In addition, molecular structure and chemical state of P can affect its burial and regeneration (Zhu et al., 2015). The solution ${ }^{31} \mathrm{P}$-nuclear magnetic resonance spectroscopy $\left({ }^{31} \mathrm{P} \quad \mathrm{NMR}\right)$ method is a powerful technology in determination for the molecular structure of $\mathrm{P}$ compounds. The ${ }^{31} \mathrm{P}$ NMR method can identify specific $\mathrm{P}$ compounds (e.g., Glucose 6-phosphate, inositol hexaphosphoric acid, monophosphate, DNA, RNA, phospholipids and polyphosphate) in EDTA and $\mathrm{NaOH}$ extraction of sediments (Cade-Menun and Preston, 1996). Inositol hexaphosphoric acid and polyphosphate are two kinds of natural metal chelating agents, which can react strongly with metal ions to form insoluble complexes (Turner et al., 2012; Huang et al., 2018). Previous studies indicated that free of glucose 6-phosphate, monophosphate and DNA can be easily hydrolyzed into $\mathrm{PO}_{4}{ }^{3-}$ by phosphatase. However, humic acid and/or metal ions associated with these OP compounds become fairly recalcitrant, which can be stably preserved in sediments (Zhu et al., 2015, 2018). Therefore, an accurate understanding of redox-dependent $\mathrm{P}$ burial and regeneration in marine sediments based on multiple methods is essential.

Sulfate reduction can produce toxic free dissolved sulfide (referred to here as $\mathrm{HS}^{-}$, dominant form at seawater $\mathrm{pH}$ ) (Kraal et al., 2017), which can precipitate with divalent metal ions including $\mathrm{Fe}^{2+/ 3+}$ to generate insoluble metallic sulfides in sediments (Ankley, 1996). Therefore, we hypothesized that the formation of insoluble metallic sulfides reduced the efficiency of metal ions combining with OP. The free OP would be easily hydrolyzed into $\mathrm{PO}_{4}{ }^{3-}$ by phosphatase after the metal ions were removed by $\mathrm{HS}^{-}$. In addition, OP can be used as electron donor during the sulfate reduction resulting in the decomposition of OP. Therefore, sulfate reduction may improve the risk of regeneration of OP.

The $\mathrm{PO}_{4}{ }^{3-}$ pollution in coastal areas often leads to toxic algal blooms, which can seriously poison marine organisms. The regeneration of internal $\mathrm{P}$ accumulated in sediments has become an important source of $\mathrm{PO}_{4}{ }^{3-}$ in coastal waters due to anthropogenic inputs of $\mathrm{PO}_{4}{ }^{3-}$ have gradually been increasingly controlled by strict environmental laws (Li et al., 2018). Therefore, the study of sedimentary P burial and regeneration is essential for controlling $\mathrm{P}$ endogenous pollution in marine. The objectives of this study were to (1) identify the potential sources of $\mathrm{P}$ and the time of algae bloom by mass ratio of total organic carbon (TOC) to total nitrogen (TN), and carbon and nitrogen isotope $\left(\delta^{13} \mathrm{C}\right.$ and $\left.\delta^{15} \mathrm{~N}\right)$; (2) investigate redox-dependent $\mathrm{P}$ burial and regeneration mechanism based on the various $P$ speciation in the presence of $\mathrm{Si}$ and $\mathrm{Al}$ composite oxides and (3) recognize the effect of sulfate reduction and pyrite formation on the regeneration of OP.

\section{Materials and methods}

\subsection{Study area and sample collection}

The sampling site $\left(37^{\circ} 46.93^{\prime} \mathrm{N}, 121^{\circ} 19.39^{\prime} \mathrm{E}\right)$ was located near Jiahe River estuary in the north Yellow Sea (NYS), China (Fig. 1), which is a typical epicontinental marginal sea with an average water depth of $\sim 38 \mathrm{~m}$ (Yang et al., 2010). The Jiahe River is one of the principal rivers along the Shandong Peninsula coast, entering the NYS with high loadings of anthropogenic material input. A sediment core ( $370 \mathrm{~cm}$ deep) was collected using a $400-\mathrm{cm}$ long polycarbonate tube with an inner diameter of $10 \mathrm{~cm}$. The deep sediment core can provide valid results and interpretations because the $\mathrm{Si}, \mathrm{Fe}, \mathrm{Al}$ and $\mathrm{Ca}$ are the inherent and extensive elements in earth's crust. Distributions and contents of $\mathrm{Si}, \mathrm{Al}, \mathrm{Fe}$ and $\mathrm{Ca}$ do not vary significantly among different sampling areas, and the rules of vertical variation of redox condition and sulfate reduction in sediments are universal in sediments. The spatial variation cannot change the above basic rules of geochemistry. Therefore, the effect mechanism of $\mathrm{Si}$, Fe and
$\mathrm{Al}$ composite oxides, redox and sulfate reduction on $\mathrm{P}$ burial and regeneration can be identified by a sediment core.

The sediment core was sectioned at intervals of $2-20 \mathrm{~cm}$. Segments of the cut sediment were stored in sealed plastic bags filled with $\mathrm{N}_{2}$ at $-20^{\circ} \mathrm{C}$, then transported to laboratory within $3 \mathrm{~h}$. Before analysis, all sediments were lyophilized and homogenized and ground to powder in a sealed $\mathrm{N}_{2}$-filled chamber.

\subsection{Chemical analysis}

Sediment samples were pretreated with $1 \mathrm{M} \mathrm{HCl}$ to remove carbonates, and then total organic carbon (TOC) and total nitrogen (TN) were determined using a Vario MACRO cube CNS analyzer (Elmentar, Germany). Subsamples after the decarbonization were selected for the organic carbon and nitrogen isotope $\left(\delta^{13} \mathrm{C}\right.$ and $\left.\delta^{15} \mathrm{~N}\right)$ analyses. $\delta^{13} \mathrm{C}$ and $\delta^{15} \mathrm{~N}$ analyses were conducted using a Delta ${ }^{\text {plus }} \mathrm{XL}$ mass spectrometer connected with a Flash EA elemental analyzer (Thermo Fisher MAT253, USA). $\delta^{13} \mathrm{C}$ and $\delta^{15} \mathrm{~N}$, reported in parts per million (\%), were calculated as follows:

$\delta \mathrm{X}(\% \mathrm{o})=\left[\left(\mathrm{R}_{\text {sample }} / \mathrm{R}_{\text {standard }}\right)-1\right] \times 10^{3}$

where $\mathrm{X}$ is ${ }^{13} \mathrm{C}$ or ${ }^{15} \mathrm{~N}$, and $\mathrm{R}_{\text {sample }}$ and $\mathrm{R}_{\text {standard }}$ are the isotopic ${ }^{13} \mathrm{C} /{ }^{12} \mathrm{C}$ ratios of the samples and standards, respectively. The carbon standard is Vienna Pee Dee Belemnite and the nitrogen standard is air. The standard error of $\delta^{13} \mathrm{C}$ and $\delta^{15} \mathrm{~N}$ analysis was below $0.2 \%$ and $0.4 \%$, respectively.

The concentrations of $\mathrm{Al}, \mathrm{Fe}, \mathrm{Ca}$ and $\mathrm{Mn}$ in sediments were determined using an inductively coupled plasma-optical emission spectroscopy (ICP-OES, Perkin-Elmer Optima 7000 DV, USA) after microwave-acid wet digestion by $\mathrm{HNO}_{3}, \mathrm{HCl}$, and $\mathrm{HF}$ (Sneddon et al., 2006). $\mathrm{The} \mathrm{Al}, \mathrm{Fe}$ and $\mathrm{Ca}$ bound silicate minerals in the adequately homogenized samples from $-2 \mathrm{~cm},-90 \mathrm{~cm},-150 \mathrm{~cm}$ and $-370 \mathrm{~cm}$ depths were analyzed with an energy dispersive X-ray micro-analyzer (EDS, EX-350, HORIBA, Japan) at an acceleration voltage $15 \mathrm{kV}$. The target elements and their composition in $\mathrm{mol} \%$ were selected and estimated using AZtec software (Dijkstra et al., 2018), which excluded carbon, sulfur, potassium, titanium, copper and chloride (manually inserted in the figures) (Figs. 2 and 3).

Chlorophyll $a$ was determined by spectrophotometry at $663 \mathrm{~nm}$ and $645 \mathrm{~nm}$ after extracting with $80 \%$ (vol\%) acetone in a dark environment at $4{ }^{\circ} \mathrm{C}$ (Arnon, 1949). Measurement of alkaline phosphatase reactivity (APA) was based on the standard pNPP ( $p$-nitrophenyl phosphate) method using a spectrophotometer at $410 \mathrm{~nm}$ (Sayler et al., 1979). The reactive $\mathrm{Fe}$ was extracted from the sediments using $1 \mathrm{~mol} \mathrm{~L}^{-1} \mathrm{HCl}$ (Wallmann et al., 1993). Total reactive $\mathrm{Fe}\left(\mathrm{Fe}_{\mathrm{RT}}\right)$ and $\mathrm{Fe}$ (II) concentrations in the extracts were determined with the colorimetric phenanthroline method (Stookey, 1970). Fe(II) and Fe $\mathrm{RT}$ were determined by measuring the absorbance before and after adding hydroxylamine-hydrochloride to reduce agent that can convert any dissolved Fe(III) to Fe(II). The Fe(III) concentration was calculated as the difference between $\mathrm{Fe}_{\mathrm{RT}}$ and $\mathrm{Fe}(\mathrm{II})$.

Reduced inorganic sulfur (RIS) pools were determined using a slight modification of the sequential extraction method of Sheng et al. (2015), as described by Newton et al. (1995) and Hsieh and Shieh (1997). The RIS was divided into acid-volatile sulfide (AVS; $6 \mathrm{~mol} \mathrm{~L}^{-1} \mathrm{HCl}, 1 \mathrm{~h}$ ), chromium-reducible sulfide (CRS or pyrite-S; $15 \mathrm{~mL}$ acidic $\mathrm{Cr}^{2+}, 2 \mathrm{~h}$ ),

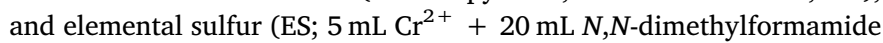
$(\mathrm{DMF})+5 \mathrm{~mL}$ concentrated $\mathrm{HCl}, 1 \mathrm{~h}$ ). The acid-volatile sulfide gives an estimate of the Fe monosulfide (FeS) (Rickard and Morse, 2005). The sulfide released as $\mathrm{H}_{2} \mathrm{~S}$ during AVS, CRS and ES extraction was trapped as $\mathrm{CuS}$ in $\mathrm{CuCl}_{2}$ traps (Newton et al., 1995). The sulfide content of the traps was determined by iodometric titration (Kramar et al., 2014). Detailed analysis steps of the above physicochemical parameters and data quality control (QC) and quality assurance (QA) are presented in the Supporting information. 


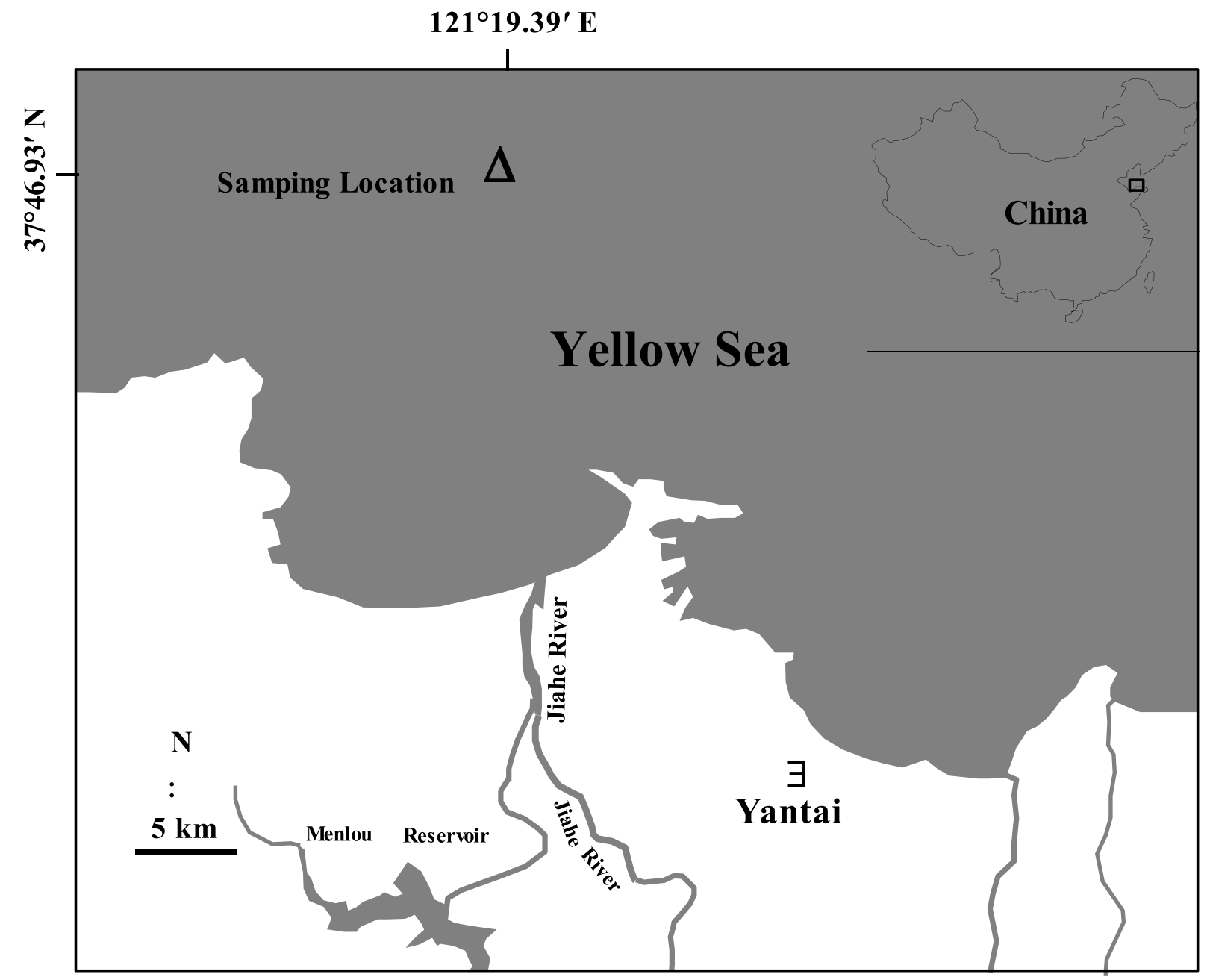

Fig. 1. Sampling location of the core sediment in the North Yellow Sea.

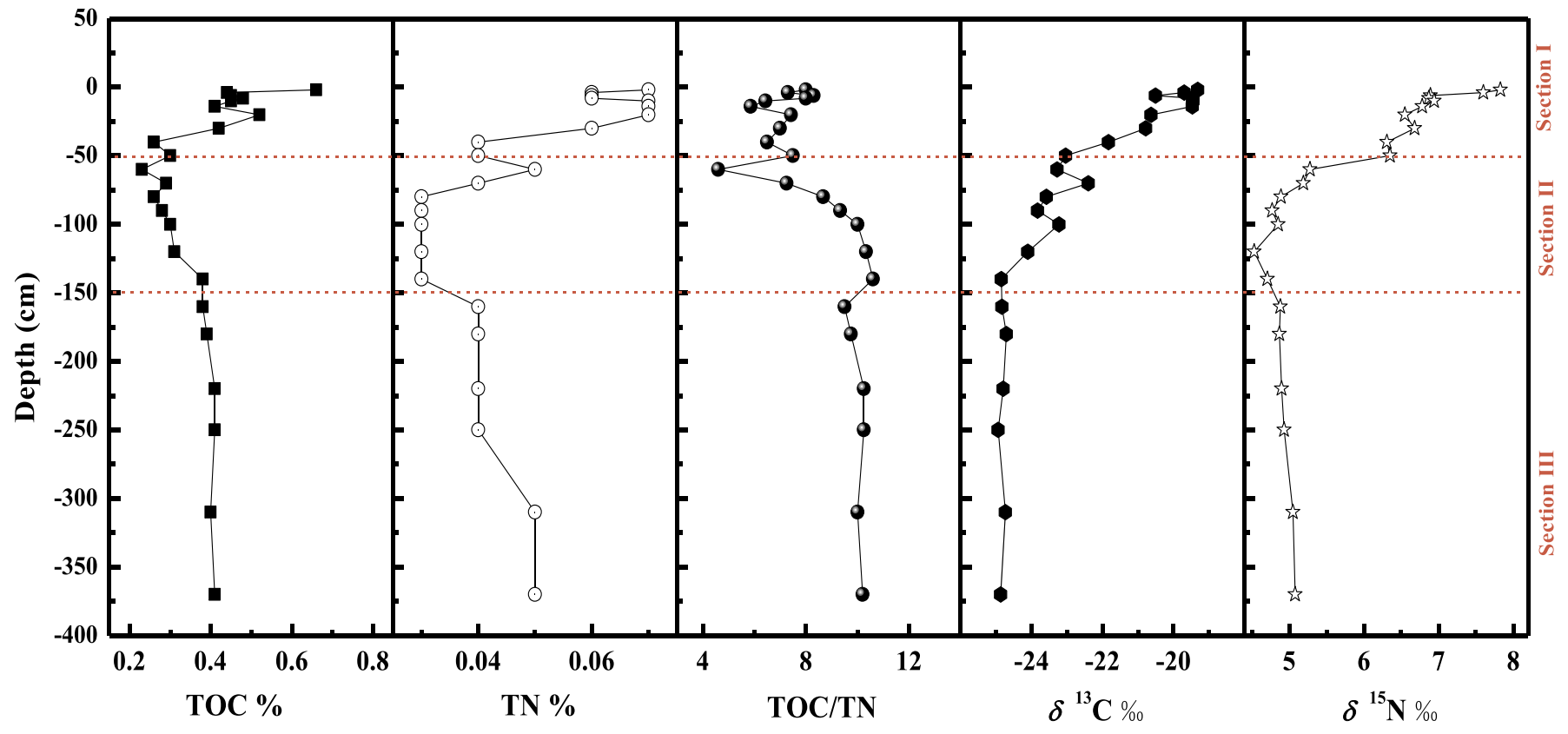

Fig. 2. Distribution of TOC, TN, TOC/TN, $\delta^{13} \mathrm{C}$ and $\delta^{15} \mathrm{~N}$. 


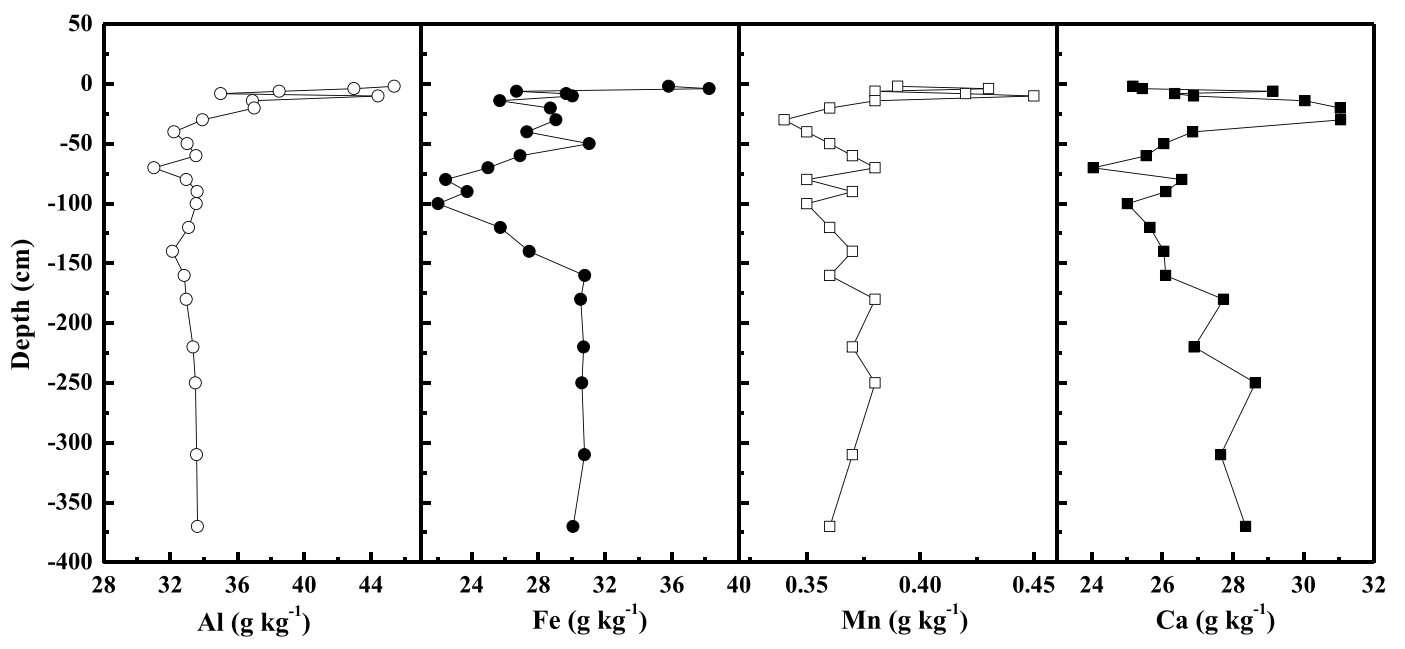

Fig. 3. Distribution of $\mathrm{Al}, \mathrm{Fe}, \mathrm{Mn}$ and $\mathrm{Ca}$ in the sediment core.

\subsection{Phosphorus sequential extraction}

The chemical sequential fractionation of IP in sediments was determined using the Standards, Measurements and Testing (SMT) protocol (Ruban et al., 2001). The extraction of $\mathrm{P}$ in the protocol was divided into $\mathrm{Al} / \mathrm{Fe} / \mathrm{Mn}-\mathrm{P}, \mathrm{Ca}-\mathrm{P}$, OP and TP. The sedimentary OP was sequentially extracted with the Ivanoff method (Ivanoff et al., 1998; Zhao et al., 2018). OP in sediments was divided into five fractions: $\mathrm{NaHCO}_{3}$-extractable OP $\left(\mathrm{NaHCO}_{3}\right.$-OP), $\mathrm{HCl}$-soluble OP (HCl-OP), OP in the form of fulvic acid (Flv-OP), humic acid (Hum-OP), and residual OP $\left(\mathrm{H}_{2} \mathrm{SO}_{4}\right.$-OP $)$. Additionally, $\mathrm{NaHCO}_{3}$-OP was defined as readily labile $\mathrm{OP}, \mathrm{HCl}-\mathrm{OP}$, Flv-OP were considered moderately labile $\mathrm{OP}$, and $\mathrm{H}_{2} \mathrm{SO}_{4^{-}}$ $\mathrm{OP}$, and Hum-OP were treated as nonlabile OP. Detailed analysis steps of the $\mathrm{P}$ chemical fractionation and data QC/QA are presented in the Supporting information.

\subsection{NaOH-EDTA extraction and ${ }^{31} P$ NMR analysis}

Using a widely applied extraction procedure, each freeze-dried sample was mixed with $\mathrm{NaOH}$-EDTA solution at a $1: 10 \mathrm{w} / \mathrm{v}$ ratio, shaken for $16 \mathrm{~h}$ at $20^{\circ} \mathrm{C}$, and centrifuged (Turner et al., 2005). Briefly, approximately $3.0 \mathrm{~g}$ of lyophilized sample was added to $30 \mathrm{~mL} \mathrm{NaOH}$ EDTA solution $\left(0.25 \mathrm{~mol} \mathrm{~L}^{-1} \mathrm{NaOH}\right.$ and $50 \mathrm{mmol} \mathrm{L}^{-1} \mathrm{Na}_{2}$ EDTA). The supernatant was collected after centrifugation at $12,000 \mathrm{rpm}$ for $30 \mathrm{~min}$. The supernatant was collected for TP and IP determination. TP in extracts was digested with $\mathrm{K}_{2} \mathrm{~S}_{2} \mathrm{O}_{8}+\mathrm{H}_{2} \mathrm{SO}_{4}$ in an autoclave at $121{ }^{\circ} \mathrm{C}$ for $30 \mathrm{~min}$ (Zhao et al., 2018). IP in extracts was directly determined without the digestion. The extracted OP was calculated as the difference between TP and IP. The recoveries of TP and OP in extracts were defined as the ratio of TP in extracts to TP in sediments, and extracted OP to OP in sediments, respectively (Zhang et al., 2008).

The remaining extracts were lyophilized for $24-48 \mathrm{~h}$ to obtain the dry extracts. Approximately $200 \mathrm{mg}$ lyophilized powder was re-dissolved in $0.6 \mathrm{~mL} \mathrm{D}_{2} \mathrm{O}$ and $0.1 \mathrm{~mL} 10 \mathrm{~mol} \mathrm{~L}^{-1} \mathrm{NaOH}$, vortexed, and centrifuged at $13,000 \mathrm{rpm}$ for $20 \mathrm{~min}$ at $4^{\circ} \mathrm{C}$. The supernatant was transferred to a 5$\mathrm{mm}$ NMR tube for analysis. The solution ${ }^{31} \mathrm{P}$ NMR spectra were obtained with an Avance III Bruker $500 \mathrm{MHz}$ spectrometer (Bruker BioSpin GmbH, Germany) at $202.47 \mathrm{MHz}$ with a $30^{\circ}$ pulse, $0.58 \mathrm{~s}$ acquisition, a $2.0 \mathrm{~s} \mathrm{~T}_{1}$ delay, and $20^{\circ} \mathrm{C}$ temperature. The spectra were collected based on approximately 10,000 scans. The free induction decay was not truncated in the sample analysis. The pulse angle, acquisition time, $\mathrm{T}_{1}$ delay, temperature and scan times were selected to obtain quantitative spectra based on a previous report (Turner et al., 2012).

The signal of $\mathrm{P}$ species spectrum was identified and quantified based on spiking experiments and the chemical shifts relative to documented data, with the orthophosphate peak in all spectra standardized to $6 \mathrm{ppm}$
(Cade-Menun, 2005, 2015). Four sediments $(-2 \mathrm{~cm},-90 \mathrm{~cm},-150 \mathrm{~cm}$ and $-370 \mathrm{~cm}$ ) were selected to conduct the standard addition experiment. The same NaOH-EDTA extractions were spiked with $\beta$-glycerophosphate disodium salt hydrate (Sigma number G5422), DL- $\alpha$-glycerol phosphate (Sigma number 17766), adenosine $5^{\prime}$ monophosphate disodium salt (Sigma number 01930), phosphocholine chloride calcium salt tetrahydrate (Sigma number P0378), $\alpha$-D-Glucose-1-phosphate disodium salt hydrate (Sigma number PG4455), D-Glucose 6-phosphate sodium salt hydrate (Sigma number V900924), and myo-Inositol hexakisphosphate dipotassium salt (Sigma number P5681) in order. Spiked samples were extracted and analyzed by ${ }^{31} \mathrm{P}$ NMR as described above.

\subsection{Statistical analysis}

Correlation analysis and data calculation were performed with SPSS 19 for Windows10 software (SPSS Inc., USA). The NMR spectra were processed with $10 \mathrm{~Hz}$ line broadening for the full spectra and $2 \mathrm{~Hz}$ line broadening to analyze the fine details of the orthophosphate monoester and diester regions. The spectra were processed using Bruker Software (TopSpin 3.5; Bruker Corporation; Germany). Corrections were made to account for phospholipid and RNA degradation by summing the peak areas associated with degradation products ( $\alpha$ - and $\beta$-glycerophosphate and mononucleotides degraded from phospholipids and RNA, respectively), subtracting this sum from the $\alpha$ - and $\beta$-glycerophosphate and mononucleotide areas and adding them to the phospholipid and RNA areas (Cade-Menun, 2015).

\section{Results}

\subsection{General sediment properties}

Based on vertical profiles of TOC, TN, TOC/TN (weight ratio), $\delta^{13} \mathrm{C}$ and $\delta^{15} \mathrm{~N}$, the sediment can be approximately categorized into three distinct stages in evolution. In the section I (from -50 to $0 \mathrm{~cm}$ ), TOC and TN gradually increased from $0.3 \%$ to $0.7 \%$ and from $0.04 \%$ to $0.07 \%$, respectively, in an upward direction. The TOC/TN was $<8$, but $\delta^{13} \mathrm{C}$ and $\delta^{15} \mathrm{~N}$ were greater than $-23 \%$ and $6.5 \%$, respectively. In the section II $(-50 \mathrm{~cm}$ to $-150 \mathrm{~cm}$ ), TOC gradually increased from $0.2 \%$ to $0.4 \%$, but $\delta^{13} \mathrm{C}$ and $\delta^{15} \mathrm{~N}$ decreased from $-23 \%$ to $-25 \%$ and $6.5 \%$ to $5 \%$, respectively. The weight ratio of TOC/TN increased from 4 to 10 . In the section III (below $-150 \mathrm{~cm}$ ), the values of TOC, TN, TOC/TN, $\delta^{13} \mathrm{C}$ and $\delta^{15} \mathrm{~N}$ kept narrow ranges. Overall, bulk isotope compositions of sediments displayed significantly positive shifts in $\delta^{13} \mathrm{C}$ and $\delta^{15} \mathrm{~N}$ $\left(r^{2}=0.85\right.$, Fig. S3a) in this sediment core. The $\delta^{13} \mathrm{C}$ and $\delta^{15} \mathrm{~N}$ were both significantly negatively correlated with TOC/TN $\left(\delta^{13} \mathrm{C}, r^{2}=0.45\right.$, Fig. S3b; $\delta^{15} \mathrm{~N}, r^{2}=0.36$, Fig. S3c). 
Concentrations of $\mathrm{Al}, \mathrm{Fe}$, and $\mathrm{Mn}$ presented the highest values in the upper $10 \mathrm{~cm}$ of the core, but the highest content of Ca was found near $-20 \mathrm{~cm}$. Distribution of Al below $-20 \mathrm{~cm}$ was stable with the content of $34 \mathrm{~g} \mathrm{~kg}^{-1}$. Fe gradually decreased from $32 \mathrm{~g} \mathrm{~kg}^{-1}$ to $22 \mathrm{~g} \mathrm{~kg}^{-1}$ between $-50 \mathrm{~cm}$ and $-100 \mathrm{~cm}$, while increased from $22 \mathrm{~g} \mathrm{~kg}^{-1}$ to $30 \mathrm{~g} \mathrm{~kg}^{-1}$ between $-100 \mathrm{~cm}$ and $-150 \mathrm{~cm}$. Fe was stable below $-150 \mathrm{~cm}$ with the content of $30 \mathrm{~g} \mathrm{~kg}^{-1}$. The content of Ca was stable at the depth between $-50 \mathrm{~cm}$ and $-150 \mathrm{~cm}$, but gradually increased from $24 \mathrm{~g} \mathrm{~kg}^{-1}$ to $28 \mathrm{~g} \mathrm{~kg}^{-1}$ below $-150 \mathrm{~cm}$. Contents of $\mathrm{Mn}$ were low and stable below $-20 \mathrm{~cm}$. The EDS showed that content of siliceous compounds dominated the composition in the whole sediment core (Fig. S1).

\subsection{Distributions of APA, Chl $a$ and reactive Fe}

Two indicators of biological reactivity (APA, Chl $a$ ) are shown in Fig. 4. APA fluctuated between $12 \mathrm{mg} \mathrm{kg}^{-1} \mathrm{~h}^{-1}$ and $57 \mathrm{mg} \mathrm{kg}^{-1} \mathrm{~h}^{-1}$, with an average of $24.7 \pm 13.5 \mathrm{mg} \mathrm{kg}^{-1} \mathrm{~h}^{-1}$. APA was high in the upper sediments ( 0 to $-20 \mathrm{~cm}$ ), then declined from $-20 \mathrm{~cm}$ to $-70 \mathrm{~cm}$. APA increased again from $-70 \mathrm{~cm}$ to $-140 \mathrm{~cm}$, and then remained stable below $-150 \mathrm{~cm}$. Chl $a$ presented the highest value above $-25 \mathrm{~cm}$, with an average of $1.8 \pm 0.8 \mathrm{mg} \mathrm{kg}^{-1}$. However, Chl $a$ decreased from -18 to $-35 \mathrm{~cm}$, reached a minimum of $0.4 \pm 0.1 \mathrm{mg} \mathrm{kg}^{-1}$ below $-35 \mathrm{~cm}$, then remained within a narrow range.

The vertical distributions of different active Fe are presented in Fig. 4. The average levels of $\mathrm{Fe}(\mathrm{II}), \mathrm{Fe}(\mathrm{III})$, and $\mathrm{Fe} \mathrm{RT}_{\text {T }}$ were $41.9 \pm$ $15.8 \mu \mathrm{mol} \mathrm{g}^{-1}$, $10.6 \pm 7.3 \mu \mathrm{molg}^{-1}$, and $52.5 \pm 12.6 \mu \mathrm{mol} \mathrm{g}^{-1}$, respectively. Both reactive $\mathrm{Fe}(\mathrm{II})$ and $\mathrm{Fe}{ }_{\mathrm{RT}}$ generally decreased above $-60 \mathrm{~cm}$, increased markedly from -60 to $-150 \mathrm{~cm}$, then became stable, with means of $56.7 \pm 2.8 \mu \mathrm{mol} \mathrm{g}^{-1}$ and $58.3 \pm 2.5 \mu \mathrm{mol} \mathrm{g}^{-1}$, respectively, below $-150 \mathrm{~cm}$. However, the reactive $\mathrm{Fe}(\mathrm{III})$ fluctuated in the upper section (from 0 to $-60 \mathrm{~cm}$ ), decreased from -60 to $-150 \mathrm{~cm}$, and stabilized below $-150 \mathrm{~cm}$. Additionally, reactive Fe(II) was significantly positive correlated with $\mathrm{Fe}_{\mathrm{RT}}\left(r^{2}=0.78\right.$, Fig. S4a) and significantly negative correlated with Fe(III) $\left(r^{2}=0.37\right.$, Fig. S4b).

\subsection{Distributions of AVS, CRS, and ES in the sediments}

As shown in Fig. 5, AVS varied from 12.2 to $40.3 \mathrm{mg} \mathrm{kg}^{-1}$ with depth. There was a high content of AVS in the upper 0 to $-8 \mathrm{~cm}$ and at the bottom of the core $(-310$ to $-370 \mathrm{~cm})$. CRS and ES fluctuated from 21.3 to $1155.6 \mathrm{mg} \mathrm{kg}^{-1}$ (average of $305.1 \pm 328.7 \mathrm{mg} \mathrm{kg}^{-1}$ ) and 8.2 to $87.1 \mathrm{mg} \mathrm{kg}^{-1}$ (average of $30.8 \pm 21.9 \mathrm{mg} \mathrm{kg}^{-1}$ ), respectively. The CRS and ES concentrations remained high in the bottom section $(-250 \mathrm{~cm}$ to

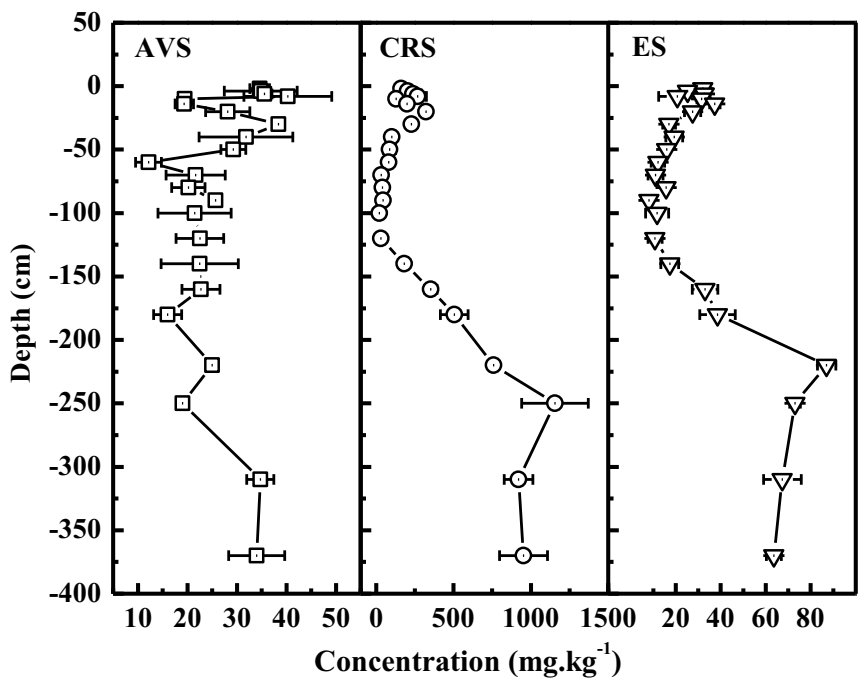

Fig. 5. Vertical distributions of AVS, CRS, and ES in the sediment profiles.

$-370 \mathrm{~cm})$ and low in the subsurface section $(-20 \mathrm{~cm}$ to $-100 \mathrm{~cm})$ in the sediment core. In addition, RIS in the core was dominated by CRS (average of $65 \pm 19 \%$ of the total RIS), with AVS and ES accounting for an average of $24 \pm 16 \%$ and $11 \pm 4 \%$, respectively.

\subsection{Fractionation of $P$ by the SMT and Ivanoff scheme}

The results of $\mathrm{P}$ fractionation by the SMT protocol in the sediments shown in Fig. 6 (I) indicate that TP ranged from $478.6 \mathrm{mg} \mathrm{kg}^{-1}$ to $552.6 \mathrm{mg} \mathrm{kg}^{-1}$ (average of $508.1 \pm 18.8 \mathrm{mg} \mathrm{kg}^{-1}$ ). Ca-P was the dominant fraction of TP in the sediments, comprising $75 \%$ to $95 \%$ of the TP (average of $426.4 \pm 20.6 \mathrm{mg} \mathrm{kg}^{-1}$ ). OP was the second-most dominant TP fraction (10\% to $15 \%)$. Al/Fe/Mn-P was the lowest TP component, accounting for $6 \%$ to $12 \%$. The distributions of TP, $\mathrm{Ca}-\mathrm{P}, \mathrm{Al} / \mathrm{Fe}$ / Mn-P, and OP by the SMT protocol in the sediment core can be divided into three general parts: they were relatively high and fluctuated in the surface sediment $(0$ to $-20 \mathrm{~cm})$, decreased with the depth $(-20$ $\sim-100 \mathrm{~cm}$ ) and remained mostly stable at lower depths. However, the decreasing trend of $\mathrm{Ca}-\mathrm{P}$ was not obvious from -20 to $-100 \mathrm{~cm}$. The $\mathrm{TP}$ and $\mathrm{Ca}-\mathrm{P}$ content increased slightly with depth below $-100 \mathrm{~cm}$.

The results in Fig. 6 (II) demonstrate that residue-OP and Flv-OP were the major fractions of OP. The residue-OP accounted for $45.8 \pm 9.6 \%$,

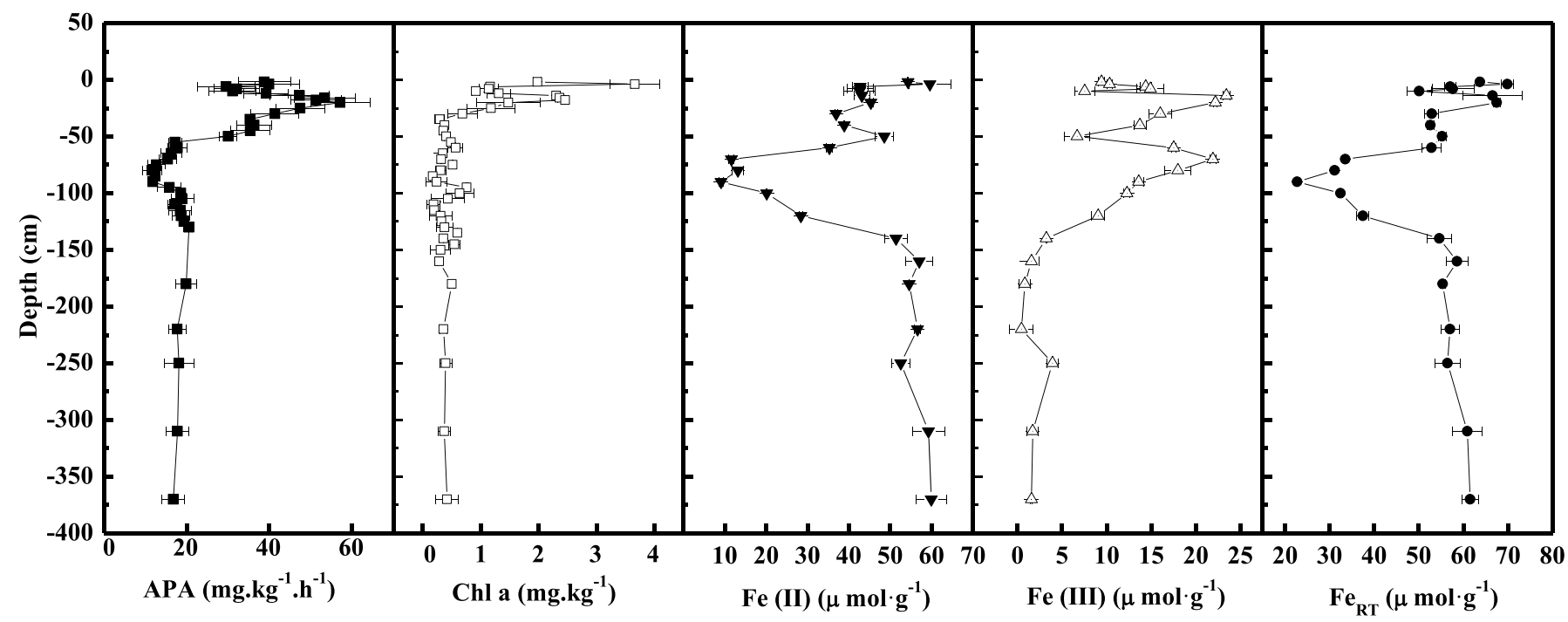

Fig. 4. Distributions of APA, $\mathrm{Chl}$ a, $\mathrm{Fe}(\mathrm{II}), \mathrm{Fe}(\mathrm{III})$ and $\mathrm{Fe}_{\mathrm{RT}}$ in the sediment profiles. 

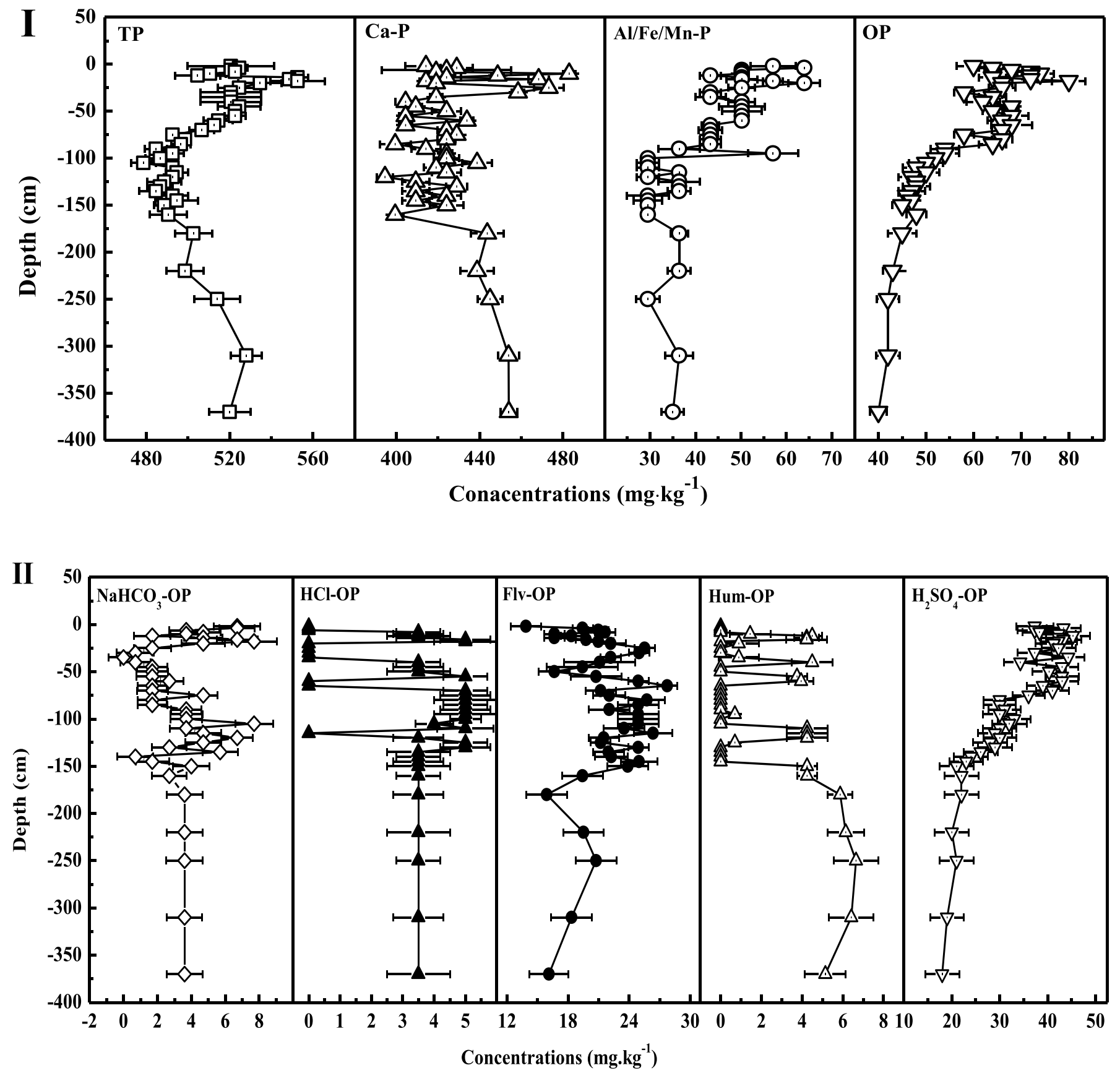

Fig. 6. Fractionation of P by the SMT (I) and Ivanoff (II) scheme in the sediment profiles.

and Flv-OP accounted for $35.8 \pm 6.6 \%$ of OP. The smallest fraction was Hum-OP accounting for $3.3 \pm 4.2 \%$ of the OP. The average residue-OP content was high in the upper section (above $-50 \mathrm{~cm}$ ). Subsequently, residue-OP dropped rapidly from 40 to $32 \mathrm{mg} \mathrm{kg}^{-1}$ from -50 to $-100 \mathrm{~cm}$, but it decreased slowly from 32 to $18 \mathrm{mg} \mathrm{kg}^{-1}$ from -100 to $-370 \mathrm{~cm}$. The Hum-OP concentrations were relatively low in the upper section (above $-150 \mathrm{~cm}$ ) but high in the deeper section (below $-110 \mathrm{~cm}$ ). Overall, Flv-OP was higher than Hum-OP.

\section{5. ${ }^{31} \mathrm{P}$ NMR spectra of $\mathrm{NaOH}-\mathrm{EDTA}$ extracts of sediments}

The NMR spectra of samples are shown in Fig. 7. Based on the spiking experiments, details of orthophosphate monoesters in sediments were identified and quantified (Fig. S2 and Table 1). The recoveries of TP and OP in NaOH-EDTA extracts were merely approximately $15 \%$ and $20 \%$, respectively (Table S1). Therefore, there should be more P compounds that could not be detected by ${ }^{31} \mathrm{P}$ NMR. And the quantified content of various $\mathrm{P}$ in Table 1 was an underestimate result. Results in Table 1 indicate that IP mainly consisted of orthophosphate and OP was dominated by orthophosphate monoesters. Phospholipid and RNA were the dominant OP species in the sediments. The glucose-6-phosphate was detected in the surface sediment, and glucose-1-phosphate was in the bottom sediment.

\section{Discussion}

\subsection{Eutrophication and source of OM in sediment}

The TOC/TN weight ratio in sediments has been widely used to interpret OM source. TOC/TN has been reported to be 5-7 for marine algae and > 15 for terrestrial C3 vascular plants (Meyers, 1997). In this work, the TOC/TN ratios in the section I (above $-50 \mathrm{~cm}$ ) were closer to the range for typical autochthonous sources than for allochthonous 


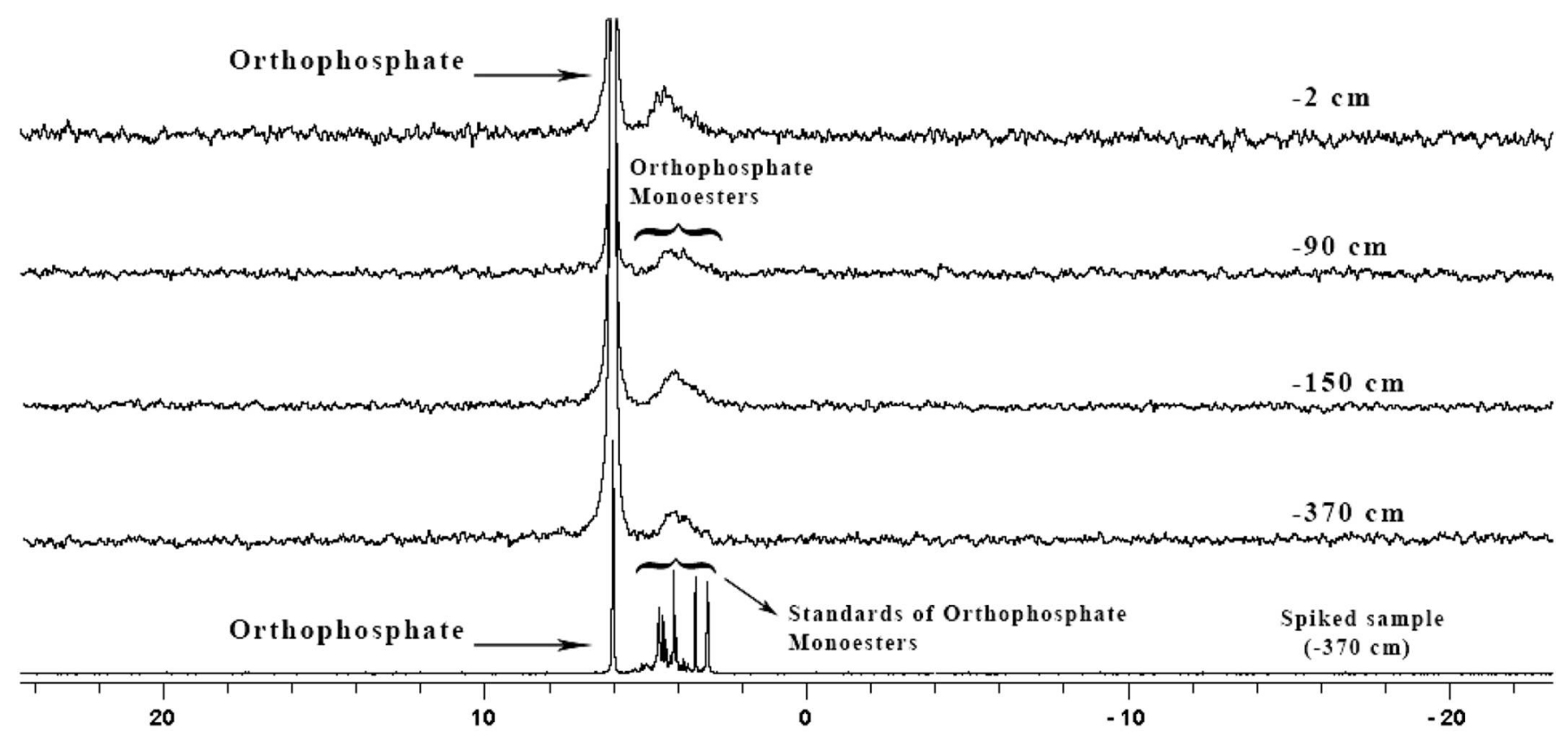

\section{Chemical Shifts (ppm)}

Fig. 7. ${ }^{31} \mathrm{P}$ NMR spectra of NaOH-EDTA extracts from the sediment core.

sources, suggesting that $\mathrm{OM}$ in the section I of the sediment core was mainly derived from algal and bacterial production in the marine water column. However, the TOC/TN ratios were gradually trending towards the range for the terrestrial plants at the depth between $-50 \mathrm{~cm}$ and $-150 \mathrm{~cm}$, which indicated that terrestrial OM inputs gradually became an important source below $-50 \mathrm{~cm}$. Unlike TOC/TN ratios, $\delta^{13} \mathrm{C}$ and $\delta^{15} \mathrm{~N}$ values are not significantly influenced by sediment grain size and degradation of labile OM, making them useful in reconstructing past sources of $\mathrm{OM}$ in places with histories of changing depositional conditions (Meyers, 1997). Therefore, combined TOC/TN ratios and $\delta^{13} \mathrm{C}$ and $\delta^{15} \mathrm{~N}$ values can more precisely distinguish between marine and continental plant sources of sedimentary OM. Phytoplankton in marine ecosystem usually have $\delta^{13} \mathrm{C}$ values from -18 to $-22 \%$ and the $\delta^{15} \mathrm{~N}$ value of dissolved $\mathrm{NO}_{3}{ }^{-}$used by marine algae is from 7 to $10 \%$. Terrestrial plants have $\delta^{13} \mathrm{C}$ value from $-25 \%$ to $-33 \%$ and $\delta^{15} \mathrm{~N}$ value of atmosphere-derived $\mathrm{N}_{2}$ that is made available to land plants by nitrogen fixers in soil is approximately $0.5 \%$ (Fry and Sherr, 1984; Xiong et al., 2010). Thus, the above conclusion was further supported by $\delta^{13} \mathrm{C}$ and $\delta^{15} \mathrm{~N}$ values. Based on the ${ }^{210} \mathrm{~Pb}$ profiles recorded in sediments from the offshore of the North Yellow Sea (Wang et al., 2017), the sediment at $-50 \mathrm{~cm}$ was accumulated during the $1970 \mathrm{~s}$. Therefore, variations in $\mathrm{OM}$ in sediment profiles indicated that there was a significant increase in the number of algae from the 1970s onwards, which suggested that the offshore sampling area of the Jiahe River estuary had entered a eutrophic or hyper-eutrophic stage in this period.

\subsection{Redox-dependent vertical burial and regeneration of $P$}

The $\mathrm{PO}_{4}{ }^{3-}$ and phytoplankton debris in the overlying water reached to the seafloor easily and accumulated in the surface sediments. Additionally, $\mathrm{Al}, \mathrm{Fe}$ and $\mathrm{Mn}$ contents were the highest in the surface sediments, resulting in a part of dissolved $\mathrm{PO}_{4}{ }^{3-}$ in the overlying water to associate with the reactive sites on the surface of $\mathrm{Fe} / \mathrm{Al}$ oxides and $\mathrm{Mn}$ oxides and convert into reactive $\mathrm{Al} / \mathrm{Fe} / \mathrm{Mn}-\mathrm{P}$. However, the other part of dissolved $\mathrm{PO}_{4}{ }^{3-}$ could also be strongly associated with unreactive $\mathrm{Al}$ or $\mathrm{Fe}$ bound silicate $(\mathrm{Al} / \mathrm{Fe}-\mathrm{Si}$ ) minerals (the unreactive $\mathrm{Fe}$ / $\mathrm{Al}$ compounds) by $\mathrm{Al}-\mathrm{OH}$ and $\mathrm{Fe}-\mathrm{OH}$ functional groups inside the $\mathrm{Al}$ / Fe-Si minerals through ion exchange (Kasama et al., 2004; Ruttenberg and Sulak, 2011). The $\mathrm{PO}_{4}{ }^{3-}$ in $\mathrm{Al} / \mathrm{Fe}-\mathrm{Si}$ minerals is called occluded Al/ Fe-Si bound $\mathrm{P}$ (Al/Fe-Si-P), which is too stable to be released under natural conditions (Liu et al., 2003). A previous study indicated that $\alpha$ Gly and $\beta$-Gly were degradation products from phospholipids and most mononucleotides originated from RNA or organisms (Cade-Menun, 2017). Settled phytoplankton debris contributed large amounts of OP in the surface sediments (Zhang et al., 2018). Surface sediments were aerobic because shallow seawater was enriched with oxygen, which could inhibit the reduction of Fe (III) oxides (hydroxides) and OP mineralization (Kraal et al., 2017). Therefore, higher concentrations of Al/ $\mathrm{Fe} / \mathrm{Mn}-\mathrm{P}$ and OP were preserved in the surface sediments. The highest content of $\mathrm{Ca}-\mathrm{P}$ was found at around $-20 \mathrm{~cm}$ just with the highest concentration of $\mathrm{Ca}$, attributing to the dissolved $\mathrm{PO}_{4}{ }^{3-}$. The $\mathrm{PO}_{4}{ }^{3-}$ can

Table 1

The relative distribution of P species determined by ${ }^{31} \mathrm{P}$ NMR spectroscopy in the NaOH-EDTA extracts.

\begin{tabular}{|c|c|c|c|c|c|c|c|c|}
\hline Sediments & \multicolumn{8}{|c|}{ Integral area (\%) } \\
\hline$-2 \mathrm{~cm}$ & $92.3 \%$ & n.d. & $2.26 \%$ & 1.04 & $0.59 \%$ & $1.08 \%$ & 1.00 & n.d. \\
\hline$-150 \mathrm{~cm}$ & $92.8 \%$ & n.d. & n.d. & $0.72 \%$ & $0.62 \%$ & $1.24 \%$ & $2.06 \%$ & $1.23 \%$ \\
\hline$-370 \mathrm{~cm}$ & $93.8 \%$ & n.d. & n.d. & n.d. & $0.48 \%$ & 0.87 & $0.86 \%$ & $0.34 \%$ \\
\hline
\end{tabular}

Note: n.d: not detected or below the LOQs. Ortho-P, orthophosphate; myo-IHP, myo-inositol hexakisphosphate; G6P, glucose-6-phosphate; ChoP, choline phosphate; G1P, glucose-1-phosphate. 
be captured by the reactive Ca compounds or unreactive calcium-bound silicate transforming into stable biological apatite, $\mathrm{CaCO}_{3}$ incorporated $\mathrm{PO}_{4}{ }^{3-}$, authigenic carbonate fluorapatite and/or occluded calciumbound silicate (Si-Ca-P) (Kang et al., 2017; Li et al., 2017). The $\mathrm{PO}_{4}{ }^{3-}$ could be preserved within the $\mathrm{Ca}$ bound silicate minerals by $\mathrm{OH}$ functional groups inside the calcium-bound silicate through ion exchange (Kasama et al., 2004). Generally, the reactive Al/Fe/Mn-P would be easily released under sulfidic conditions (Li et al., 2016). In this study, the $\mathrm{Al} / \mathrm{Fe} / \mathrm{Mn}-\mathrm{P}$ showed a sharp decrease from the upper sediment to the deep sediment. Most released $\mathrm{Al} / \mathrm{Fe} / \mathrm{Mn}-\mathrm{P}$ should be reactive $\mathrm{Al} / \mathrm{Fe}$ / $\mathrm{Mn}-\mathrm{P}$, rather than occluded $\mathrm{Al} / \mathrm{Fe}-\mathrm{Si}-\mathrm{P}$. More specifically, redox-dependent $\mathrm{P}$ regeneration of reactive $\mathrm{Al} / \mathrm{Fe} / \mathrm{Mn}-\mathrm{P}$ was the reactive $\mathrm{Fe}$ bound $\mathrm{P}(\mathrm{Fe}-\mathrm{P})$. Previous studies indicated that $\mathrm{Al}$ bound $\mathrm{P}(\mathrm{Al}-\mathrm{P})$ and Ca bound $\mathrm{P}(\mathrm{Ca}-\mathrm{P})$ were essential inorganic components contributing to $\mathrm{P}$ retention in sediment, but they are not impacted by changes in redox potential (Alvarez-Rogel et al., 2007; Li et al., 2017). And the occluded $\mathrm{Al} / \mathrm{Fe}-\mathrm{Si}-\mathrm{P}$ within the silicate lattice could avoid the regeneration under natural conditions (Matsue and Wada, 1989; Liu et al., 2003; Nasr et al., 2018; Zhu et al., 2018). Additionally, the residual $\mathrm{Al} / \mathrm{Fe} / \mathrm{Mn}-\mathrm{P}$ below $-100 \mathrm{~cm}$ was roughly constant, which could be stable as $\mathrm{Al} / \mathrm{Fe}-\mathrm{Si}-\mathrm{P}$ and $\mathrm{Al}-\mathrm{P}$.

However, the $\mathrm{Ca}-\mathrm{P}$ was relatively stable and difficult to be released for phytoplankton uptake (Qin and Zhu, 2006). Thus, $\mathrm{Ca}-\mathrm{P}$ was a key burial phase in the sediments. Part of the $\mathrm{PO}_{4}{ }^{3-}$ regenerated from the $\mathrm{Fe}-\mathrm{P}$ and $\mathrm{OP}$ under reduced and alkaline phosphatase conditions could diffuse downward and adsorb onto clay or $\mathrm{CaCO}_{3}$ to convert to authigenic carbonate apatite during early diagenesis (Ruttenberg and Berner, 1993). The other part of the released $\mathrm{PO}_{4}{ }^{3-}$ could diffuse upward to be absorbed by the $\mathrm{Al} / \mathrm{Fe} / \mathrm{Mn}$ in the oxidizing condition (Zhu et al., 2018). Thus, there were two $\mathrm{P}$ "pumps" in the sediments. One was the $\mathrm{Fe} / \mathrm{Al}$ / Mn oxides in the upper sediment core; the other one was the Ca minerals in the lower sediment core, which could drive the released $\mathrm{PO}_{4}{ }^{3-}$ to be buried as $\mathrm{Al} / \mathrm{Fe} / \mathrm{Mn}-\mathrm{P}$ and $\mathrm{Ca}-\mathrm{P}$ fractions. This resulted in the sharp increase in $\mathrm{Al} / \mathrm{Fe} / \mathrm{Mn}-\mathrm{P}$ and $\mathrm{Ca}-\mathrm{P}$ content from the middle of sediment core to the upper sediments and the lower sediments. Ca content gradually increased below $-160 \mathrm{~cm}$, leading to more $\mathrm{PO}_{4}{ }^{3-}$ associated with reactive Ca compounds and/or Ca bound silicate, which could be another significant factor leading to the increase in $\mathrm{Ca}-\mathrm{P}$ (apatite and/or Si-Ca-P) below $-160 \mathrm{~cm}$.

The recoveries of TP and OP in EDTA-NaOH extracts were both low mainly because high salinity reduced the extraction efficiency of EDTA$\mathrm{NaOH}$ (Zhao et al., 2019b). And a high content of $\mathrm{Ca}-\mathrm{P}$ and low content of TOC in sediment could also result in a lower recovery of $P$ due to abundant unreactive $\mathrm{P}$ chelates firmly adhering to sediments (Zhu et al., 2018). Therefore, there should be more unreactive $P$ compounds in the sediment core that could not be detected by ${ }^{31} \mathrm{P}$ NMR because the recoveries of TP and OP were only approximately $15 \%$ and $20 \%$, respectively. Ivanoff results further confirmed that there were more stable OP fractions and less reactive OP fractions in the marine sediment profile. A previous study indicated that some reactive OP (e.g., DNA, Glucose-1-phosphate, Glucose-6-phosphate, and phospholipid) chelated with metal ions or minerals to transform stable OP (Zhu et al., 2018). Generally, marine sediments contain abundant metal ions and unreactive minerals. Most of the reactive OP could chelate the humic acid and/or minerals to generate the recalcitrant OP chelates (Zhu et al., 2015). The OP metal chelates could be resistant to hydrolysis by phosphatase that could be stably preserved in sediments (Zhu et al., 2018). From the above, unreactive $\mathrm{Al} / \mathrm{Fe}-\mathrm{Si}-\mathrm{P}, \mathrm{Al}-\mathrm{P}, \mathrm{Ca}-\mathrm{P}$ and $\mathrm{OP}$ metal chelates could be stably buried in anaerobic deep sediments, while free $\mathrm{OP}$ and reactive $\mathrm{Al} / \mathrm{Fe} / \mathrm{Mn}-\mathrm{P}$ could be easily regenerated.

\subsection{Sulfate reduction and pyritization promoted $O P$ regeneration}

The anaerobic decomposition of OP could act as electron donor during the Fe (III) reduction and sulfate reduction (Henneke et al., 1997), which promoted the regeneration of OP under anaerobic conditions.
There are two competitive pathways for Fe (III) reduction: one is microbial iron reduction (MIR) combined with OM oxidation (Eq. (1)), the other is chemical iron reduction (CIR) mainly by sulfide produced by sulfate reduction (Eq. (2)) (Canfield et al., 2005). Only when the sulfide is limited does MIR dominate in sediments (Wang and VanCappellen, 1996; Wijsman et al., 2002). In this study, the concentration of AVS, CRS and ES was low above $-100 \mathrm{~cm}$ suggesting that the production of sulfide was limited. Therefore, MIR dominated Fe (III) reduction rather than CIR above $-100 \mathrm{~cm}$. AVS, CRS and ES gradually increased below $-100 \mathrm{~cm}$ indicated that sulfides began to accumulate and the sulfate reduction gradually stronger. CIR would dominate the reaction instead of MIR under sufficient $\mathrm{HS}^{-}$conditions below $-100 \mathrm{~cm}$. The enhanced reductive condition promoted sulfate reduction with $\mathrm{HS}^{-}$accumulation in the deep sediments (Eq. (3)). Therefore, OP was decomposed as electron donor under the Fe (III) reduction that was mainly occurred above $-100 \mathrm{~cm}$, and OP decomposed as electron donor under the sulfate reduction was mainly occurred below $-100 \mathrm{~cm}$.

$\mathrm{CH}_{2} \mathrm{O}+4 \mathrm{FeOOH}+8 \mathrm{H}^{+}=\mathrm{CO}_{2}+4 \mathrm{Fe}^{2+}+7 \mathrm{H}_{2} \mathrm{O}$

$2 \mathrm{FeOOH}+3 \mathrm{H}_{2} \mathrm{~S}+4 \mathrm{H}^{+}=2 \mathrm{FeS}+\mathrm{S}^{0}+4 \mathrm{H}_{2} \mathrm{O}$

$\mathrm{SO}_{4}{ }^{2-}+2 \mathrm{CH}_{2} \mathrm{O}=\mathrm{H}_{2} \mathrm{~S}+2 \mathrm{HCO}_{3}-$

$\mathrm{FeS}+\mathrm{H}_{2} \mathrm{~S}=\mathrm{FeS}_{2}$

Previous studies reported that OP associated with metals was a stable complex form that was resistant to biotic or abiotic hydrolysis (Turner et al., 2012; Zhu et al., 2015). In this study, the accumulated HS $^{-}$from sulfate reduction below $-100 \mathrm{~cm}$ could preferentially combine with metal ions including Fe(II) forming metal sulfides precipitation (Kraal et al., 2017), which reduced the efficiency of $\mathrm{M}^{\mathrm{n}+}$ combining with OP generating stable OP- $\mathrm{M}^{\mathrm{n}+}$ and/or OP- $\mathrm{M}^{\mathrm{n}+}-\mathrm{OM}$ complex $\left(\mathrm{M}^{\mathrm{n}+}\right.$, metal ions). The free OP would be easily hydrolyzed by alkaline phosphatase after the metal ions were removed by HS ${ }^{-}$(Zhu et al., 2015, 2018; Zhao et al., 2019a). Therefore, residue-OP dropped obviously with the accumulation of AVS and CRS below $-100 \mathrm{~cm}$. The formation of metal sulfides precipitation could promote the mineralization of OP. In addition, the free soluble $\mathrm{HS}^{-}$is recognized as a biological toxicant that can poison cells, genes and enzymes due to its acidity and oxidative stress (Chen et al., 2019). And the toxicity of free soluble $\mathrm{HS}^{-}$and metal ions to phosphatase has been reported by Zhao et al. (2019a). Therefore, many trace metal ions and freely soluble $\mathrm{HS}^{-}$can be collectively eliminated by the formation of metal sulfides precipitations (Jong and Parry, 2003). And the inhibited phosphatase activity could be restored after the elimination of free soluble $\mathrm{HS}^{-}$and metal ions (Zhao et al., 2019a). Therefore, APA increased with the formation of AVS and CRS below $-100 \mathrm{~cm}$. The formation of insoluble metal sulfides precipitation promoted the release of $\mathrm{PO}_{4}{ }^{3-}$ from OP. Therefore, sulfate reduction and pyritization promoted partial stable OP regeneration.

\section{Conclusion}

The indigenous biological input was the primary source of $\mathrm{OM}$ in the upper sediments. Most released $\mathrm{Al} / \mathrm{Fe} / \mathrm{Mn}-\mathrm{P}$ under reducing conditions should be reactive $\mathrm{Fe}-\mathrm{P}$, rather than unreactive $\mathrm{Al} / \mathrm{Fe}-\mathrm{Si}-\mathrm{P}$ and $\mathrm{Al}-\mathrm{P}$. The regeneration of $\mathrm{PO}_{4}{ }^{3-}$ from free OP is the sediment core mainly caused by the sulfate reduction and hydrolysis by phosphatase. The released $\mathrm{PO}_{4}{ }^{3-}$ from $\mathrm{Fe}-\mathrm{P}$ and $\mathrm{OP}$ could be captured by the $\mathrm{Al} / \mathrm{Fe}$ / $\mathrm{Mn}$ (oxyhydr) oxides and $\mathrm{Ca}$ minerals to transform into $\mathrm{Al} / \mathrm{Fe} / \mathrm{Mn}-\mathrm{P}$ and $\mathrm{Ca}-\mathrm{P}$. The $\mathrm{Ca}-\mathrm{P}, \mathrm{Al}-\mathrm{P}$, unreactive $\mathrm{Al} / \mathrm{Fe}-\mathrm{Si}-\mathrm{P}$ and some of stable metal chelated OP were the main burial fraction of P. However, sulfate reduction and formation of insoluble metallic sulfides including pyritization could promote partial non-labile OP decomposition by anaerobic decomposition, removing metal ions from the " $\mathrm{M}^{\mathrm{n}+}-\mathrm{OP}$ " chelates and restoring phosphatase activity. 


\section{Acknowledgments}

This study was supported by the Strategic Priority Research Program of the Chinese Academy of Sciences (Grant No.:XDA23050203) and National Natural Science Foundation of China (Grant No.:41373100). Additional support was provided by the Key Project of Research and Development Plan of Yantai (Grant No.: 2018ZHGY083) and the Key Research and Development Program of Shandong Province (Grant No. 2019GSF109002).

\section{Appendix A. Supplementary data}

Supplementary data to this article can be found online at https:// doi.org/10.1016/j.marpolbul.2019.110582.

\section{References}

Alvarez-Rogel, J., Jimenez-Carceles, F.J., Egea-Nicolas, C., 2007. Phosphorus retention in a coastal salt marsh in SE Spain. Sci. Total Environ. 378, 71-74.

Ankley, G.T., 1996. Evaluation of metal/acid-volatile sulfide relationships in the prediction of metal bioaccumulation by benthic macroinvertebrates. Environ. Toxicol. Chem. 15, 2138-2146.

Arnon, D.I., 1949. Copper enzymes in isolated chloroplasts - polyphenoloxidase in betavulgaris. Plant Physiol. 24, 1-15.

Cade-Menun, B.J., 2005. Characterizing phosphorus in environmental and agricultural samples by P-31 nuclear magnetic resonance spectroscopy. Talanta 66, 359-371.

Cade-Menun, B.J., 2015. Improved peak identification in 31P-NMR spectra of environmental samples with a standardized method and peak library. Geoderma 257-258, $102-114$.

Cade-Menun, B.J., 2017. Characterizing phosphorus forms in cropland soils with solution 31P-NMR: past studies and future research needs. Chem. Biol. Technol. Agric. 4, 19.

Cade-Menun, B., Liu, C.W., 2014. Solution phosphorus-31 nuclear magnetic resonance spectroscopy of soils from 2005 to 2013: a review of sample preparation and experimental parameters. Soil Sci. Soc. Am. J. 78, 19-37.

Cade-Menun, B.J., Preston, C.M., 1996. A comparison of soil extraction procedures for P31 NMR spectroscopy. Soil Sci. 161, 770-785.

Canfield, D.E., Erik, K., Bo, T., 2005. References. In: Canfield, D.E., Kristensen, E., Thamdrup, B. (Eds.), Advances in Marine Biology. Academic Press, pp. 517-599.

Carpenter, S.R., 2008. Phosphorus control is critical to mitigating eutrophication. Proc. Natl. Acad. Sci. U. S. A. 105, 11039-11040.

Chen, M., Li, X., Shi, Q., Zhang, Z., Xu, S., 2019. Hydrogen sulfide exposure triggers chicken trachea inflammatory injury through oxidative stress-mediated FOS/IL8 signaling. J. Hazard. Mater. 368, 243-254.

Dijkstra, N., Kraal, P., Séguret, M.J.M., Flores, M.R., Gonzalez, S., Rijkenberg, M.J.A., Slomp, C.P., 2018. Phosphorus dynamics in and below the redoxcline in the Black Sea and implications for phosphorus burial. Geochim. Cosmochim. Acta 222, 685-703.

Eijsink, L.M., Krom, M.D., Herut, B., 2000. Speciation and burial flux of phosphorus in the surface sediments of the Eastern Mediterranean. Am. J. Sci. 300, 483-503.

Fry, B., Sherr, E.B., 1984. Delta-c-13 measurements as indicators of carbon flow in marine and fresh-water ecosystems. Contrib. Mar. Sci. 27, 13-47.

Henneke, E., Luther, G.W., deLange, G.J., Hoefs, J., 1997. Sulphur speciation in anoxic hypersaline sediments from the eastern Mediterranean Sea. Geochim. Cosmochim. Acta 61, 307-321.

Hsieh, Y.P., Shieh, Y.N., 1997. Analysis of reduced inorganic sulfur by diffusion methods: improved apparatus and evaluation for sulfur isotopic studies. Chem. Geol. 137, 255-261.

Huang, R., Wan, B., Hultz, M., Diaz, J.M., Tang, Y., 2018. Phosphatase-mediated hydrolysis of linear polyphosphates. Environ. Sci. Technol. 52, 1183-1190.

Ivanoff, D.B., Reddy, K.R., Robinson, S., 1998. Chemical fractionation of organic phosphorus in selected histosols. Soil Sci. 163, 36-45.

Jong, T., Parry, D.L., 2003. Removal of sulfate and heavy metals by sulfate reducing bacteria in short-term bench scale upflow anaerobic packed bed reactor runs. Water Res. 37, 3379-3389.

Kang, X., et al., 2017. Phosphorus speciation and its bioavailability in sediments of the Jiaozhou Bay. Estuar. Coast. Shelf Sci. 188, 127-136.

Kasama, T., Watanabe, Y., Yamada, H., Murakami, T., 2004. Sorption of phosphates on Al-pillared smectites and mica at acidic to neutral pH. Appl. Clay Sci. 25, 167-177.

Kraal, P., Dijkstra, N., Behrends, T., Slomp, C.P., 2017. Phosphorus burial in sediments of the sulfidic deep Black Sea: key roles for adsorption by calcium carbonate and apatite authigenesis. Geochim. Cosmochim. Acta 204, 140-158.

Kramar, A.D., Žekić, A.A., Obradović, B.M., Kuraica, M.M., Kostić, M.M., 2014. Study of interaction between nitrogen DBD plasma-treated viscose fibers and divalent ions $\mathrm{Ca} 2+$ and $\mathrm{Cu} 2+$. Cellulose 21, 3279-3289.

Krom, M.D., Berner, R.A., 1980. Adsorption of phosphate in anoxic marine-sediments. Limnol. Oceanogr. 25, 797-806.

Li, Z., Sheng, Y., Yang, J., Burton, E.D., 2016. Phosphorus release from coastal sediments: impacts of the oxidation-reduction potential and sulfide. Mar. Pollut. Bull. 113, 176-181.
Li, C., et al., 2017. Effect of calcium silicate hydrates (CSH) on phosphorus immobilization and speciation in shallow lake sediment. Chem. Eng. J. 317, 844-853.

Li, M., Tang, Y., Lu, X.-Y., Zhang, Z., Cao, Y., 2018. Phosphorus speciation in sewage sludge and the sludge-derived biochar by a combination of experimental methods and theoretical simulation. Water Res. 140, 90-99.

Liu, L., Liu, X., Xu, Q., Ge, X., Wang, Y., 2003. Phosphorous species and their distribution characters in sediments of miyun reservoir. Rock Miner. Anal. 22, 81-85.

Matsue, N., Wada, K., 1989. Source minerals and formation of partially interlayered vermiculites in dystrochrepts derived from tertiary sediments. J. Soil Sci. 40, 1-7.

Meyers, P.A., 1997. Organic geochemical proxies of paleoceanographic, paleolimnologic, and paleoclimatic processes. Org. Geochem. 27, 213-250.

Nasr, S.M., Okbah, M.A., El-Anany, W.I., Soliman, N.F., 2018. Chemical fractionation of aluminium in the sediments of El-Burullus Lagoon of Nile Delta, Egypt. Geochem. Int. 56, 182-188.

Newton, R.J., Bottrell, S.H., Dean, S.P., Hatfield, D., Raiswell, R., 1995. An evaluation of the use of the chromous chloride reduction method for isotopic analyses of pyrite in rocks and sediment. Chem. Geol. 125, 317-320.

Qin, B., Zhu, G., 2006. The nutrient forms, cycling and exchange flux in the sediment and overlying water system in lakes from the middle and lower reaches of Yangtze River. Sci. China Ser. D Earth Sci. 49, 1-13.

Rickard, D., Morse, J.W., 2005. Acid volatile sulfide (AVS). Mar. Chem. 97, 141-197.

Ruban, V., Lopez-Sanchez, J.F., Pardo, P., Rauret, G., Muntau, H., Quevauviller, P., 2001 Harmonized protocol and certified reference material for the determination of extractable contents of phosphorus in freshwater sediments - a synthesis of recent works. Fresenius J. Anal. Chem. 370, 224-228.

Ruttenberg, K.C., Berner, R.A., 1993. Authigenic apatite formation and burial in sediments from non-upwelling, continental margin environments. Geochim. Cosmochim. Acta 57, 991-1007.

Ruttenberg, K.C., Sulak, D.J., 2011. Sorption and desorption of dissolved organic phosphorus onto iron (oxyhydr)oxides in seawater. Geochim. Cosmochim. Acta 75, 4095-4112.

Sayler, G.S., Puziss, M., Silver, M., 1979. Alkaline-phosphatase assay for freshwater sediments - application to perturbed sediment systems. Appl. Environ. Microbiol. 38, 922-927.

Sheng, Y., Sun, Q., Bottrell, S.H., Mortimer, R.J.G., 2015. Reduced inorganic sulfur in surface sediment and its impact on benthic environments in offshore areas of NE China. Environ. Sci. Process. Impacts 17, 1689-1697.

Smith, S.V., 1984. Phosphorus versus nitrogen limitation in the marine-environment. Limnol. Oceanogr. 29, 1149-1160.

Sneddon, J., Hardaway, C., Bobbadi, K., Reddy, A., 2006. Sample preparation of solid samples for metal determination by atomic spectroscopy - an overview and selected recent applications. Appl. Spectrosc. Rev. 41, 1-14.

Stookey, L.L., 1970. Ferrozine - a new spectrophotometric reagent for iron. Anal. Chem. $42,779-781$.

Story, S., Bowen, B.B., Benison, K.C., Schulze, D.G., 2010. Authigenic phyllosilicates in modern acid saline lake sediments and implications for Mars. J. Geophys. Res. Planets 115.

Sun, Q., Sheng, Y., Yang, J., Di Bonito, M., Mortimer, R.J.G., 2016. Dynamic characteristics of sulfur, iron and phosphorus in coastal polluted sediments, north China. Environ. Pollut. 219, 588-595.

Turner, B.L., Cade-Menun, B.J., Condron, L.M., Newman, S., 2005. Extraction of soil organic phosphorus. Talanta 66, 294-306.

Turner, B.L., Cheesman, A.W., Godage, H.Y., Riley, A.M., Potter, B.V.L., 2012. Determination of neo- and D-chiro-inositol hexakisphosphate in soils by solution P-31 NMR spectroscopy. Environ. Sci. Technol. 46, 4994-5002.

Wallmann, K., Hennies, K., Konig, I., Petersen, W., Knauth, H.D., 1993. New procedure for determining reactive fe(iii) and fe(ii) minerals in sediments. Limnol. Oceanogr. 38, 1803-1812.

Wang, Y.F., VanCappellen, P., 1996. A multicomponent reactive transport model of early diagenesis: application to redox cycling in coastal marine sediments. Geochim. Cosmochim. Acta 60, 2993-3014.

Wang, Z.-H., Guo, X., Zhang, K., Lu, X.-X., 2017. Environmental changes in Jiaozhou Bay of northern China during the past 90years using metals and biogenic elements in sediments. J. Environ. Sci. 53, 301-312.

Wijsman, J.W.M., Herman, P.M.J., Middelburg, J.J., Soetaert, K., 2002. A model for early diagenetic processes in sediments of the continental shelf of the Black Sea. Estuar. Coast. Shelf Sci. 54, 403-421.

Xiong, Y., Wu, F., Fang, J., Wang, L., Li, Y., Liao, H., 2010. Organic geochemical record of environmental changes in Lake Dianchi, China. J. Paleolimnol. 44, 217-231.

Yang, J., Zhang, G.-L., Zheng, L.-X., Zhang, F., Zhao, J., 2010. Seasonal variation of fluxes and distributions of dissolved methane in the North Yellow Sea. Cont. Shelf Res. 30, 187-192.

Zhang, W., Jin, X., Meng, X., Tang, W., Shan, B., 2018. Phosphorus transformations at the sediment water interface in shallow freshwater ecosystems caused by decomposition of plant debris. Chemosphere 201, 328-334. https://doi.org/10.1016/j.chemosphere. 2018.03 .006$.

Zhao, G., Sheng, Y., Wang, J., Li, Z., Yang, J., 2018. Optimized digestion methods: organic phosphorus sequential extraction, total phosphorus, and nitrogen simultaneous determination in sediments. J. Soils Sediments 18, 2072-2080.

Zhao, G., Sheng, Y., Li, C., Liu, Q., 2019a. Effects of macro metals on alkaline phosphatase activity under conditions of sulfide accumulation. Sci. Total Environ. https://doi.org/ 10.1016/j.scitotenv.2019.134151.

Zhao, G., Sheng, Y., Jiang, M., Zhou, H., Zhang, H., 2019b. The biogeochemical 
characteristics of phosphorus in coastal sediments under high salinity and dredging conditions. Chemosphere 215, 681-692.

Zhu, M., Zhu, G., Li, W., Zhang, Y., Zhao, L., Gu, Z., 2013. Estimation of the algal-

available phosphorus pool in sediments of a large, shallow eutrophic lake (Taihu, China) using profiled SMT fractional analysis. Environ. Pollut. 173, 216-223.

Zhu, Y., Wu, F., He, Z., Giesy, J.P., Feng, W., Mu, Y., Feng, C., Zhao, X., Liao, H., Tang, Z.,
2015. Influence of natural organic matter on the bioavailability and preservation of organic phosphorus in lake sediments. Chem. Geol. 397, 51-60.

Zhu, Y., Feng, W., Liu, S., He, Z., Zhao, X., Liu, Y., Guo, J., Giesy, J.P., Wu, F., 2018.

Bioavailability and preservation of organic phosphorus in lake sediments: insights from enzymatic hydrolysis and 31P nuclear magnetic resonance. Chemosphere 211, 50-61. 